\title{
Recurrent hypoglycaemia in a patient with type 1 diabetes
}

\author{
Hiang Leng Tan, Rashmi Manjunatha, David Barton
}

Department of Diabetes and Endocrinology, Princess Royal Hospital, Telford, UK

\section{Correspondence to} Dr Hiang Leng Tan, hiangleng@doctors.org.uk

Accepted 7 July 2014

\section{CrossMark}

To cite: $\operatorname{Tan} \mathrm{HL}$,

Manjunatha $\mathrm{R}$, Barton D.

BMJ Case Rep Published

online: [please include Day

Month Year] doi:10.1136/

bcr-2014-205613

\section{DESCRIPTION}

A 31-year-old woman with a 20-year history of type 1 diabetes presented with a 2-month history of recurrent disabling hypoglycaemia. Common causes of hypoglycaemia which included excess insulin, missing meals and unaccustomed exercise had been excluded. She did not have evidence of gastroparesis, her coeliac antibody screen was negative and her renal function was normal. However, a short synacthen test (SST) failed to show a cortisol response with a peak cortisol response of $166 \mathrm{nmol} / \mathrm{L}$ at $60 \mathrm{~min}$. A static pituitary profile was subsequently performed showing an adrenocorticotropic hormone level of $<5 \mathrm{ng} / \mathrm{L}$ indicating secondary hypoadrenalism and an inappropriately normal thyroidstimulating hormone, low free T4 and T3 and low gonadotrophin, all pointing towards pituitary abnormality. MRI confirmed a pituitary adenoma with a high signal on T1, suggestive of recent bleeding into it (pituitary apoplexy) (figure 1). Since our patient had no neuro-opthalmic signs, she was managed conversatively ${ }^{1}$ with a plan to rescan the pituitary in 12 months' time. She was established on hydrocortisone and thyroxine replacement.

Classical pituitary apoplexy refers to a clinical syndrome, characterised by sudden onset headache,

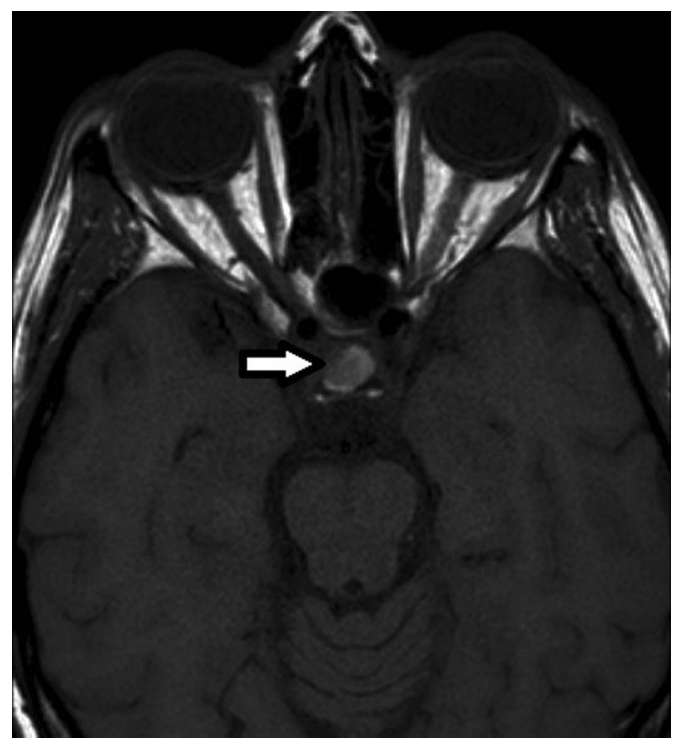

Figure 1 With arrow: MRI pitutary showing evidence of bleeding into a pituitary adenoma (pituitary apoplexy). vomiting, visual impairment and decreased consciousness caused by infarction or haemorrhage into a pituitary gland. ${ }^{1}$ However, not all patients with pituitary haemorrhage necessarily develop the apopletic syndrome. ${ }^{2}$ Furthermore, an abnormal SST does not differentiate between primary and secondary hypoadrenalism and should always be investigated further. The diagnosis of pituitary apoplexy in this patient would have been missed if a pituitary profile followed by an MRI pituitary was not performed.

\section{Learning points}

- The majority of episodes of hypoglycaemia in type 1 diabetes patients are due to a combination of missing or delaying a meal, too much insulin and unplanned exercise. However, more uncommon causes, for example, gastroparesis, malabsorption (coeliac disease), primary hypothyroidism, diabetic nephropathy and hypoadrenalism ${ }^{3}$ should be considered.

- An abnormal short synacthen test should always be further evaluated with adenocorticotropic hormone levels to differentiate between primary and secondary hypoadrenalism.

- Pituitary apoplexy can present without the classical symptoms, and can be found incidentally only on pituitary imaging.

Competing interests None.

Patient consent Obtained.

Provenance and peer review Not commissioned; externally peer reviewed.

\section{REFERENCES}

1 Rajasekaran S, Vanderpump M, Baldeweg SE, et al. UK guidelines for the management of pituitary apoplexy. Clin Endocrinol (Oxf) 2011;74:9-20

2 Mohr G, Hardy J. Haemorrhage, necrosis and apoplexy in pituitary adenomas. Surg Neurol 1982;18:181-9.

3 Likhari T, Magzoub S, Griffiths MJ, et al. Screening for Addison's disease in patients with type 1 diabetes mellitus and recurrent hypoglycaemia. Postgrad Med J 2007;83:420-1. 


\section{Images in...}

Copyright 2014 BMJ Publishing Group. All rights reserved. For permission to reuse any of this content visit http://group.bmj.com/group/rights-licensing/permissions.

BMJ Case Report Fellows may re-use this article for personal use and teaching without any further permission.

Become a Fellow of BMJ Case Reports today and you can:

- Submit as many cases as you like

- Enjoy fast sympathetic peer review and rapid publication of accepted articles

- Access all the published articles

- Re-use any of the published material for personal use and teaching without further permission

For information on Institutional Fellowships contact consortiasales@bmjgroup.com

Visit casereports.bmj.com for more articles like this and to become a Fellow 